\title{
Four DNA polymorphisms in the LDL receptor gene: their genetic relationship and use in the study of variation at the LDL receptor locus
}

\author{
ROHAN TAYLOR*, MOHAMED JEENAH*, MARY SEED†, \\ AND STEVE HUMPHRIES * \\ From *The Charing Cross Sunley Research Centre, Lurgan Avenue, London W6 8LW; and †Charing Cross \\ Hospital Medical School, St Dunstan's Road, London W6 8RF.
}

SUMMARY We have studied four different restriction fragment length polymorphisms (RFLPs) for the LDL receptor gene, detected using the restriction enzymes StuI, PvuII, ApaLI, and NcoI, in normal subjects and in patients with familial hypercholesterolaemia (FH) from London. Significant linkage disequilibrium was detected between all four RFLPs. Used together they give a polymorphism information content (PIC) of $>0.7$ which makes them useful for studying the inheritance of the LDL receptor gene in more than $70 \%$ of families with FH. The NcoI and ApaLI RFLPs were found to be the most useful, giving a combined PIC value of 0.6 . The allele frequencies of all four polymorphisms were compared in the normal and $\mathrm{FH}$ groups and the frequency of the rarer N2 allele of the NcoI RFLP was found to be significantly higher in the FH group. This suggests that a mutation has occurred on the rare $N c o I N 2$ allele and that it may be making a significant contribution to the defects causing $\mathrm{FH}$ in this patient group. We have also used these RFLPs to look for evidence that variation at the LDL receptor gene locus contributes to the determination of cholesterol levels in the normal population. People with different RFLP genotypes do not have significantly different levels of serum total or LDL cholesterol. At present we have no evidence that variation at this locus may be determining cholesterol levels in the nonFH population.

Familial hypercholesterolaemia (FH) is a common autosomal dominant disease with a heterozygote frequency of about 1 in 500 . It is clinically characterised by raised serum and LDL cholesterol levels, tendon xanthomata, and an increased risk of myocardial infarction after the second decade of life. ${ }^{1-3}$ Over recent years it has been shown that FH is caused by mutations in the gene for the low density lipoprotein (LDL) receptor. ${ }^{45}$ This receptor is found on the surface of all cells and its normal function is to bind and internalise the cholesterol rich LDL particles. Defects in receptor function lead directly to the raised blood cholesterol levels which cause the development of atherosclerosis and premature coronary artery disease. It is therefore highly advantageous to identify affected subjects at a young age before they develop symptomatic disease, in order to give advice on diet and prophylactic treatment with drugs to reduce their future

Received for publication 10 November 1987.

Revised version accepted for publication 29 February 1988. risk of myocardial infarction. It has been shown that measurement of total or LDL cholesterol levels does not always allow unequivocal diagnosis of $\mathbf{F H}$, especially in children, ${ }^{67}$ since these values may fall in the upper range of normal. One study ${ }^{6}$ estimated that $4.25 \%$ of children with one parent heterozygous for FH could not be diagnosed equivocally by these means alone.

The cloning of the LDL receptor gene ${ }^{8}$ has now made it possible to analyse mutations causing $\mathrm{FH}$ at the DNA level. To date, at least 16 different mutations have been described in detail,,${ }^{9-19}$ but there are likely to be many more than this number. Gross structural alterations to the gene, such as deletions or insertions, can be detected directly using Southern blotting techniques and we have recently shown that about $4 \%$ of $\mathrm{FH}$ patients in London have these detectable deletions. ${ }^{19}$ However, the majority of defects are probably the result of point mutations and will require other methods for diagnosis. 
Over the last two years, 10 restriction fragment length polymorphisms (RFLPs) in the LDL receptor gene have been reported using eight different enzymes. ${ }^{20-27}$ These can be used as markers to follow the inheritance of a defective receptor gene indirectly in a family by linkage analysis. ${ }^{27-29}$ Thus, in families where some members have $\mathrm{FH}$, it may be possible to carry out unequivocal diagnosis in children whose age adjusted serum cholesterol levels are within the normal range, but who have inherited a defective LDL receptor gene. In this study we have examined the usefulness of four common RFLPs of the LDL receptor gene, all detected using the same probe, for the diagnosis of $\mathrm{FH}$ in the London population.

It has recently been shown that variation at the apolipoprotein (apo) E gene locus contributes as much as $8 \%$ of the phenotypic variance in cholesterol levels in the general population. ${ }^{30} 31$ Therefore, it is likely that variation in other genes that are involved in lipid metabolism, such as apo B or the LDL receptor, may also contribute to the determination of cholesterol levels in the normal population. We have attempted to study the effect of variation at the LDL receptor locus on normal lipid levels by examining the mean cholesterol levels of subjects with different LDL receptor RFLP genotypes.

\section{Materials and methods}

BLOOD SAMPLES

Blood samples were collected from normal healthy Caucasian men and women representative of the non-FH population in London, who had completed a Rose questionnaire to exclude the presence of ischaemic heart disease. They were aged 45 to 59 years with a mean total cholesterol of $5 \cdot 6(\mathrm{SD} 1.02) \mathrm{mmol} / \mathrm{l}$ and mean triglyceride 1.7 (SD 0.95$) \mathrm{mmol} / \mathrm{l}$. This normal population included subjects with sporadic hypercholesterolaemia but excluded persons with familial hypercholesterolaemia. The other characteristics of this control sample will be presented elsewhere (R Houlston et al, in preparation). Blood samples were also collected from Caucasian patients with heterozygous $\mathrm{FH}$, attending the lipid clinics at Charing Cross and Hammersmith Hospitals. Standard criteria for diagnosis of FH were used. ${ }^{32}$ Briefly these were: total serum cholesterol levels above $6.7 \mathrm{mmol} / \mathrm{l}$ owing to serum LDL cholesterol levels above $4.9 \mathrm{mmol} / \mathrm{l}$, accompanied by tendon xanthomata and xanthomata or hypercholesterolaemia in a first degree relative. A total of $10 \mathrm{ml}$ of whole venous blood was collected into EDTA tubes and stored at $-20^{\circ} \mathrm{C}$ until DNA extraction was carried out.
PROBES FOR THE LDL RECEPTOR GENE

The 3' gene probe used was pLDLR-2HH1, a kind gift from Dr D W Russell, Dallas, USA. This plasmid contains a $1.9 \mathrm{~kb}$ fragment of the full length receptor cDNA (bp 1573 to 3486 ). This is equivalent to the designated $1.9 \mathrm{~kb} \mathrm{BamHI}$ fragment of the full length receptor cDNA pLDLR3. The insert was cut out by digestion with BamHI (Anglian Biotech) and separated from the vector fragment by electrophoresis on a $1 \%$ low melting point agarose gel. The $1.9 \mathrm{~kb}$ fragment was excised from the gel and boiled in water. The probe was labelled to a specific radioactivity of $>10^{8} \mathrm{cpm} / \mu \mathrm{g}$ by random hexanucleotide priming ${ }^{33}$ using $\left[{ }^{32} \mathrm{P}\right] \mathrm{dCTP}$ at $800 \mathrm{Ci} /$ mmol (Amersham).

\section{DNA ANALYSIS}

Total genomic DNA was extracted from white blood cells using a Triton X-100 lysis method. A total of $5 \mu \mathrm{g}$ of DNA was digested using the restriction enzymes StuI, PvuII, ApaLI plus BamHI, and NcoI (Anglian Biotech) at a concentration of 2 to $4 \mathrm{U} / \mu \mathrm{g}$ DNA. Restriction fragments were size separated by electrophoresis on $0.8 \%$ or $1 \%$ agarose gels and transferred to Hybond-N nylon membranes (Amersham) by Southern blotting. ${ }^{34}$ DNA was fixed by UV treatment or baking at $80^{\circ} \mathrm{C}$ and filters were prehybridised for at least 10 minutes at $65^{\circ} \mathrm{C}$ in $7 \%$ sodium dodecyl sulphate (SDS), $0.5 \mathrm{~mol} / 1$ phosphate buffer, $\mathrm{pH} 7 \cdot 0$. Hybridisation was carried out in $50 \mathrm{ml}$ tubes in rotating ovens (Bachofer, West Germany) at $65^{\circ} \mathrm{C}$ in $3 \mathrm{ml}$ of the same solution plus $3 \times 10^{5} \mathrm{cpm}$ of denatured radiolabelled probe. After at least 16 hours' hybridisation, the filters were washed to a stringency of $1 \times$ SSC, $0.1 \%$ SDS for 30 minutes at $65^{\circ} \mathrm{C}$. Filters were exposed to $x$ ray film using an intensifying screen at $-70^{\circ} \mathrm{C}$ for one to three days.

\section{CALCULATION OF $\Delta$}

The correlation coefficient $\Delta$ was used to determine the degree of linkage disequilibrium between two RFLP loci $A$ and $B$. It was calculated from the equation below:

$$
\Delta=\frac{a d-b c}{\sqrt{(a+b)(c+d)(a+c)(b+d)}}
$$

$a, b, c$, and $d$ being the frequencies of the haplotypes A1B1, A1B2, A2B1, and A2B2 respectively. The $95 \%$ confidence limits of $\Delta$ were calculated using the $\mathrm{Z}$ transformation where $\mathrm{Z}=\tanh ^{-1} \Delta$ and $\mathrm{Z}$ has normal distribution with standard error of

$$
\frac{1.96}{\sqrt{n-3}} \text {. }
$$


Pairwise PIC values were calculated from the observed frequency of the haplotypes in the control population. For subjects heterozygous for both polymorphisms, the relative frequency of the two possible haplotypes was determined from the frequency of the unambiguously observed haplotypes, using an estimation maximisation algorithm. ${ }^{35}$

STATISTICAL ANALYSIS

$\chi^{2}$ analysis was used to test the hypothesis of random association between the alleles of two particular RFLPs. Statistical significance was considered to be at the 0.05 level. The lipid variables were corrected for height, weight, age, and sex differences by polynomial regression. One way analysis of variance was used to test for association of the RFLPs with phenotypic variation. Analysis was carried out using the MINITAB program (State College, Pennsylvania).

\section{Results}

The LDL receptor gene fragments detected by the $3^{\prime}$ receptor cDNA probe in Southern blot hybridisations using the four different enzyme digests are shown in fig 1 . Fig 2 shows a map of the $3^{\prime}$ half of the LDL receptor gene with positions of the varying enzyme sites marked and the approximate sizes of the hybridising fragments shown below the map. The varying StuI site is the nearest to the $5^{\prime}$ end of the gene, while the $A p a \mathrm{LI}$ and $P v u I I$ varying sites are close together in intron 15 . Our preliminary mapping data indicate that the varying $\mathrm{Nco}$ I site is at the $3^{\prime}$ end of the gene.

Table 1 shows the genotype distribution and relative allele frequency in both the normal and FH sample examined for all four RFLPs. None of the genotype distributions differed significantly from that expected for a sample in Hardy Weinberg equilibrium. The frequency of the PvuII, StuI, and ApaLI RFLPs did not differ significantly between the two populations. However, the frequency of the common allele (N1) of the NcoI RFLP is 0.74 in the control sample but a lower frequency of 0.63 is observed in the sample of $\mathrm{FH}$ subjects, and this difference is statistically significant $\left(\chi^{2}=5 \cdot 20,1 \mathrm{df}\right.$, $\mathrm{p}<0.025$ by gene counting) .

In table 2 correlation coefficient $(\Delta)$ values are presented for all six pairwise combinations of the four polymorphisms with the confidence limits to examine whether there is a significant deviation from $\Delta=0$ (that is, linkage disequilibrium). The $\Delta$ values are similar in the control group and in the patients with FH (not shown). The pairwise polymorphism information content (PIC) values are also presented in table 2. The highest value is 0.61 for the NcoI and ApaLI polymorphisms, which makes these RFLPs the most informative when used together. The StuI polymorphism has the lowest rare allele frequency and a PIC value of 0.1 (table 1) when
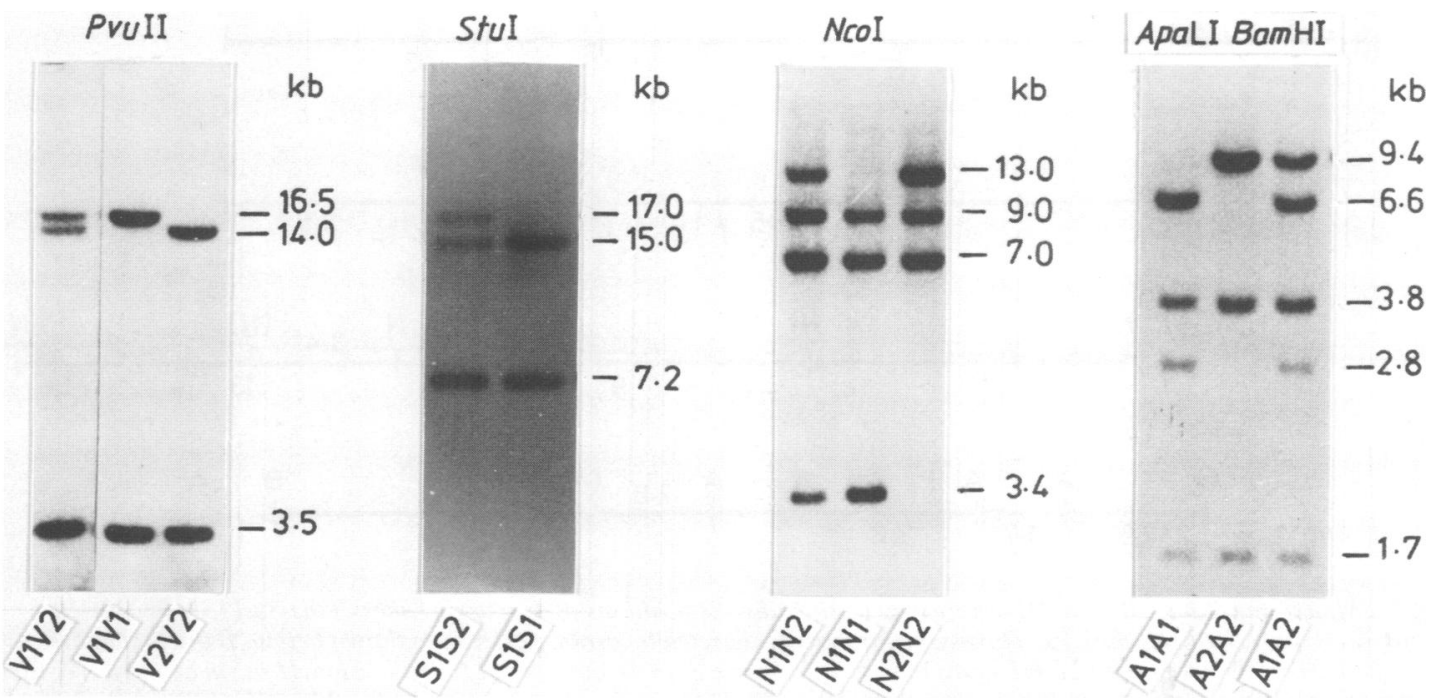

FIG 1 Southern blot hybridisation with the 3' LDL receptor cDNA probe 2 2HH1 using four different restriction enzyme digests, StuI, PvuII, ApaLI/BamHI, and NcoI, to detect the four RFLPs. In each we have designated the rare allele S2, V2, $A 2$, and N2. 
TABLE 1 Genotype distribution and relative allele frequency of the StuI, PvuII, ApaLI, and NcoI RFLPs in controls and FH patients from London.

\begin{tabular}{|c|c|c|c|c|c|}
\hline \multirow[b]{2}{*}{ StuI } & \multicolumn{3}{|c|}{$\begin{array}{l}\text { Genotype } \\
\text { distribution }\end{array}$} & \multirow{2}{*}{$\begin{array}{l}\begin{array}{l}\text { Relative allele } \\
\text { frequency }\end{array} \\
\text { S1/S2 }\end{array}$} & \multirow{2}{*}{$\begin{array}{l}\begin{array}{l}\text { PIC } \\
\text { value }\end{array} \\
0.10\end{array}$} \\
\hline & S1S1 & S1S2 & S2S2 & & \\
\hline Controls $(n=154)$ & 138 & 15 & 1 & $0.94 / 0.06$ & \\
\hline FH $(n=61)$ & 56 & 5 & $\mathbf{0}$ & $0.96 / 0.04$ & \\
\hline PvuII & V1V1 & V1V2 & $\mathrm{V} 2 \mathrm{~V} 2$ & $\mathbf{V} 1 / \mathrm{V} 2$ & 0.31 \\
\hline Controls $(n=147)$ & 79 & & 7 & $0.75 / 0 \cdot 25$ & \\
\hline FH $(n=59)$ & 33 & 24 & 2 & $0.76 / 0.24$ & \\
\hline ApaLI & A1A1 & A1A2 & A2A2 & A1/A2 & 0.37 \\
\hline Controls $(n=66)$ & 18 & & 15 & $0.52 / 0.48$ & \\
\hline FH $(n=53)$ & 16 & 28 & 9 & $0.56 / 0.44$ & \\
\hline NcoI & N1N1 & N1N2 & N2N2 & N1/N2 & 0.31 \\
\hline Controls & 60 & 52 & 5 & $0.74 / 0.26$ & \\
\hline FH $(n=126)$ & 50 & 61 & 15 & $0.63 / 0.37^{*}$ & \\
\hline
\end{tabular}

$\chi^{2}=5 \cdot 20,1$ df by gene counting $(p<0.025)$.

$\begin{array}{ll}\text { StuI } & \mathrm{S} 1=15+7 \cdot 2 \mathrm{~kb} . \\ & \mathrm{S} 2=17+7 \cdot 2 \mathrm{~kb} . \\ \text { PvuII } & \mathrm{V} 1=16 \cdot 5 \quad+3 \cdot 5 \mathrm{~kb} . \\ & \mathrm{V} 2=14 \cdot 0+2 \cdot 5+3 \cdot 5 \mathrm{~kb} . \\ \text { ApaLI BamHI I } & \mathrm{A} 1=6 \cdot 6+2 \cdot 8+3 \cdot 8+1 \cdot 7 \mathrm{~kb} . \\ & \mathrm{A} 2=9 \cdot 4+3 \cdot 8+1 \cdot 7 \mathrm{~kb} . \\ \text { NcoI } & \mathrm{N} 1=3 \cdot 4+7+9 \mathrm{~kb} . \\ & \mathrm{N} 2=13+7+9 \mathrm{~kb} .\end{array}$

used on its own, and it does not provide significant extra information when combined with any of the other RFLPs.

Since PIC values are highest for the ApaLI and NcoI RFLPs (table 1), we have compared the relative genotype frequency when using the four RFLPs in conjunction with using the NcoI and ApaLI RFLPs only (table 3). When using the two RFLPs only, $71 \%$ of the control population and $84 \%$ of the FH group are heterozygous for one or both polymorphisms. Using the four RFLP genotypes, we found that $76 \%$ of the controls and $86 \%$ of the FH group were heterozygous for at least one

TABLE $2 \Delta$ values and PIC values of the pairwise combinations of four RFLPs.

\begin{tabular}{lllll}
\hline & $\Delta$ value $^{*}$ & $\begin{array}{l}95 \% \text { confidence } \\
\text { limits }\end{array}$ & No & $\begin{array}{l}\text { Combined } \\
\text { PIC value }\end{array}$ \\
\hline PvuII-NcoI & 0.35 & $0 \cdot 195-0.487$ & 69 & 0.57 \\
PvuII-StuI & 0.43 & $0.282-0.557$ & 69 & 0.37 \\
PvuII-ApaLI & 0.63 & $0.514-0.723$ & 66 & 0.54 \\
NcoI-StuI & 0.18 & $0.013-0.337$ & 69 & 0.43 \\
NcoI-ApaLI & 0.35 & $0 \cdot 191-0.492$ & 66 & 0.61 \\
StuI-ApaLI & 0.30 & $0.136-0.448$ & 66 & 0.47
\end{tabular}

*All $\Delta$ values are significantly different from $0(\mathrm{p}<0.05)$, that is, linkage disequilibrium.
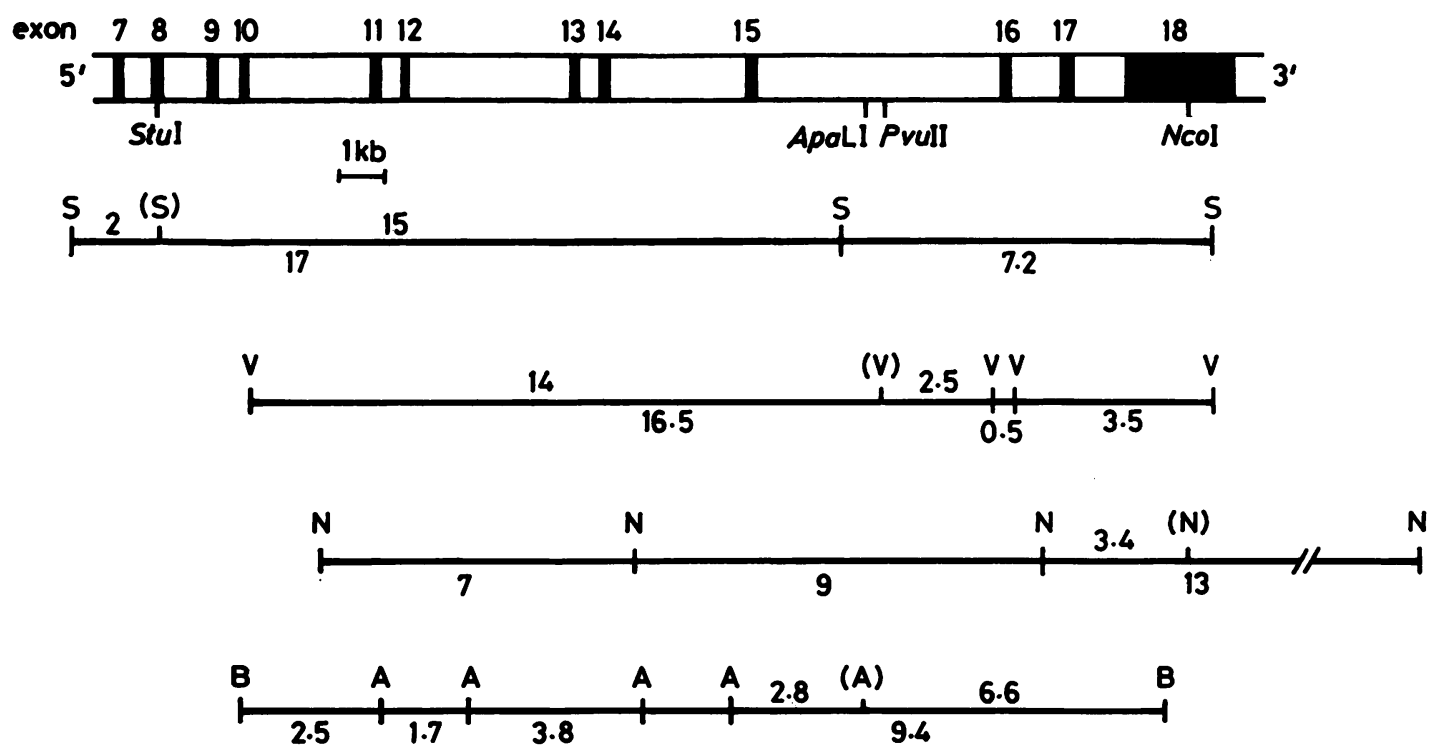

FIG 2 Map of the $3^{\prime}$ half of the LDL receptor gene showing the positions of the varying sites of the StuI (S), PvuII (V), ApaLI $(A)$, and NcoI $(N)$ RFLPs. The fragments that are detected by probe $2 H H 1$ are shown below. BamHI sites are marked B. The cDNA probe $2 \mathrm{HH1}$ spans the exons from the BamHI site in exon 10 to the BamHI site in exon 18 . We used double NcoI/StuI digests to map the varying NcoI site to the Alu repeat region of exon 18. The $13 \mathrm{~kb}$ NcoI fragment is reduced to $3.6 \mathrm{~kb}$ by the StuI cutting site in exon 18 and the $9 \mathrm{~kb}$ NcoI fragment is reduced to $5 \mathrm{~kb}$ by the StuI site in intron 15. The $7 \mathrm{~kb}$ and $3.4 \mathrm{~kb}$ Ncol fragments remain uncut by StuI digestion. This map has been confirmed by the use of an exon 13 and 14 specific cDNA probe (cut out of $2 \mathrm{HH1}$ ) which hybridises to the $7 \mathrm{~kb}$ NcoI fragment only (not shown). 
polymorphism and therefore potentially informative for diagnosis of FH.

We have also used the polymorphisms to see if we

TABLE 3 Genotype distribution in controls and FH patients using either two or four RFLPs.

\begin{tabular}{|c|c|c|c|c|c|c|c|}
\hline \multicolumn{4}{|c|}{ Genotype } & \multicolumn{2}{|c|}{ Controls } & \multicolumn{2}{|l|}{$F H$} \\
\hline \multicolumn{2}{|l|}{ Ncol } & \multicolumn{2}{|l|}{ ApaLI } & No & $\begin{array}{l}\text { Relative } \\
\% \text { of } \\
\text { total }\end{array}$ & No & $\begin{array}{l}\text { Relative } \\
\% \text { of } \\
\text { total }\end{array}$ \\
\hline \multicolumn{2}{|l|}{11} & \multicolumn{2}{|l|}{12} & 16 & 24 & 11 & 21 \\
\hline \multicolumn{2}{|l|}{12} & \multicolumn{2}{|l|}{12} & 16 & 24 & 14 & 27 \\
\hline \multicolumn{2}{|l|}{11} & \multicolumn{2}{|l|}{11} & 13 & 20 & 8 & $15 \cdot 5$ \\
\hline \multicolumn{2}{|l|}{12} & \multicolumn{2}{|l|}{22} & 9 & 14 & 8 & $15 \cdot 5$ \\
\hline \multicolumn{2}{|l|}{12} & \multicolumn{2}{|l|}{11} & 5 & $7 \cdot 5$ & 7 & $13 \cdot 5$ \\
\hline \multicolumn{2}{|l|}{11} & \multicolumn{2}{|l|}{22} & 4 & 6 & 0 & 0 \\
\hline \multicolumn{2}{|l|}{22} & \multicolumn{2}{|l|}{22} & 2 & 3 & 0 & 0 \\
\hline \multicolumn{2}{|l|}{22} & \multicolumn{2}{|l|}{12} & 1 & 1.5 & 4 & $7 \cdot 5$ \\
\hline \multicolumn{4}{|l|}{ Total } & \multicolumn{2}{|l|}{66} & \multicolumn{2}{|l|}{52} \\
\hline \multicolumn{5}{|c|}{ Heterozygous for least 1 RFLP } & \multicolumn{2}{|l|}{$=71 \%$} & $=84 \%$ \\
\hline StuI & PvulI & ApaLI & NcoI & No & $\begin{array}{l}\text { Relative } \\
\% \text { of } \\
\text { total }\end{array}$ & No & $\begin{array}{l}\text { Relative } \\
\% \text { of } \\
\text { total }\end{array}$ \\
\hline 11 & 11 & 12 & 12 & 14 & 21 & 8 & 15 \\
\hline 11 & 11 & 11 & 11 & 13 & 20 & 7 & $13 \cdot 5$ \\
\hline 11 & 12 & 12 & 11 & 13 & 20 & 9 & 17 \\
\hline 11 & 12 & 22 & 12 & 7 & $10 \cdot 5$ & 6 & $11 \cdot 5$ \\
\hline 11 & 11 & 11 & 12 & 5 & $7 \cdot 5$ & 7 & $13 \cdot 5$ \\
\hline 12 & 22 & 22 & 11 & 3 & $4 \cdot 5$ & 0 & 0 \\
\hline 12 & 12 & 12 & 11 & 3 & $4 \cdot 5$ & 0 & 0 \\
\hline 11 & 12 & 12 & 12 & 2 & 3 & 5 & $9 \cdot 5$ \\
\hline 11 & 11 & 22 & 22 & 2 & 3 & 0 & 0 \\
\hline 12 & 12 & 22 & 12 & 2 & 3 & 1 & 2 \\
\hline 11 & 11 & 12 & 22 & 1 & 1.5 & 3 & 6 \\
\hline 22 & 22 & 22 & 11 & 1 & 1.5 & 0 & 0 \\
\hline 12 & 22 & 22 & 12 & 0 & 0 & 1 & 2 \\
\hline 12 & 12 & 12 & 12 & 0 & 0 & 1 & 2 \\
\hline 11 & 12 & 12 & 22 & 0 & 0 & 1 & 2 \\
\hline 12 & 11 & 11 & 11 & 0 & 0 & 1 & 2 \\
\hline 11 & 11 & 12 & 11 & 0 & 0 & 2 & 4 \\
\hline \multicolumn{4}{|l|}{ Total } & 66 & & 52 & \\
\hline
\end{tabular}

TABLE 4 Mean cholesterol levels of subjects in the normal London population with different RFLP genotypes.

\begin{tabular}{lrll}
\hline Genotype & No & $\begin{array}{l}\text { Mean cholesterol } \\
\text { level }(\mathrm{mmol} / \mathrm{l})(\mathrm{SD})\end{array}$ & F statistic \\
\hline S1S1 & 138 & $5.64(0.93)$ & $\mathrm{F}=1.50$ \\
S1S2 & 15 & $5.31(1.07)$ & $(\mathrm{p}>0.05)$ \\
S2S2 & 1 & $4.49(-)$ & \\
V1V1 & 79 & $5.60(0.91)$ & $\mathrm{F}=0.69$ \\
V1V2 & 61 & $5.48(0.94)$ & $(\mathrm{p}>0.05)$ \\
V2V2 & 7 & $5.88(1.14)$ & \\
A1A1 & 18 & $5.51(0.94)$ & $\mathrm{F}=0.53$ \\
A1A2 & 33 & $5.26(0.87)$ & $(\mathrm{p}>0.05)$ \\
A2A2 & 15 & $5.27(0.72)$ & \\
N1N1 & 34 & $5.35(0.86)$ & $\mathrm{F}=0.08$ \\
N1N2 & 32 & $5.31(0.89)$ & $(\mathrm{p}>0.05)$ \\
N2N2 & 3 & $5.51(0.22)$ & \\
\hline
\end{tabular}

Cholesterol levels are adjusted for age, sex, height, and weight. can detect significant differences in cholesterol levels in groups of subjects with different RFLP genotypes. Table 4 gives the mean cholesterol levels in normal subjects with different LDL receptor RFLP genotypes. When one way analysis of variance was carried out, no significant differences in cholesterol levels were found associated with the different genotypes, although subjects with the $\mathrm{S} 2$ allele have lower levels of cholesterol. No differences in LDL cholesterol or apo B levels were found in subjects with different RFLP genotypes (data not shown).

\section{Discussion}

There are now several effective lipid lowering drugs and therapies available to treat patients with $\mathrm{FH}$ and to reduce their risk of coronary artery disease. Once detected either by conventional biochemical methods or by genetic tests, affected subjects can be given advice with regard to other risk factors (smoking, diet, and exercise) and prophylactic drug therapy for the hypercholesterolaemia to lessen the risk of development of premature atherosclerosis. One of the aims of this study was therefore to determine the usefulness of four RFLPs of the LDL receptor gene as linkage markers for diagnosis in families with known FH. The usefulness of such polymorphisms for family (linkage) studies depends on the relative frequency of the alleles and the degree of linkage disequilibrium between the alleles of the different polymorphisms.

The frequency of the PvuII RFLP in this sample is the same as previously reported for the London population. ${ }^{27}$ The StuI RFLP was first reported in the South African Afrikaner population ${ }^{21}$ where the frequency of the common S1 allele was found to be $\mathbf{0 . 9 2}$, which is not significantly different from the frequency we observe here. The NcoI RFLP was also reported in South African Caucasians ${ }^{22}$ where the frequency of the $\mathrm{N} 1$ allele is 0.64 compared to 0.74 in the London population. This difference is not statistically significant and might be the result of chance variation in the small samples studied, or may reflect the different ethnic origins of the two populations. The ApaLI RFLP in intron 15 was reported to have a frequency for the $6.6 \mathrm{~kb}$ allele (A1) of 0.43 when measured in 13 American Caucasians, but we have found the frequency of the A1 allele in the London sample to be 0.52 , which makes it more useful than previously thought.

The four polymorphisms are all clustered in the $3^{\prime}$ half of the gene with the StuI site being nearest to the $5^{\prime}$ end in exon 8 and the $N c o I$ site nearest to the $3^{\prime}$ end in exon 18. If there were linkage equilibrium (random association of the alleles) between the four 
RFLPs, we would expect their combined PIC value to be greater than 0.9 . However, there is significant linkage disequilibrium between all of them which reduces the overall PIC value to approximately $0 \cdot 7$. Over such small genetic distances the degree of linkage disequilibrium is not related primarily to the physical distance between the varying genetic markers, but is rather the result of the evolutionary history of the four polymorphisms. However, the data are consistent with the physical map of the location of the polymorphisms.

For linkage studies, most of the information can be obtained by using only the two polymorphisms Apa LI and NcoI, whose combined PIC value is 0.61. This means that, using these two RFLPs alone, roughly two thirds of $\mathrm{FH}$ families will be informative for genetic studies. It is likely that some of the other RFLPs that have been recently reported, but not used in this study, ${ }^{23-26}$ will be additionally useful for early diagnosis of $\mathrm{FH}$ in families or occasionally for prenatal diagnosis where both parents have heterozygous FH.

We have also compared the frequency of LDL receptor RFLPs in FH patients and the normal population in London. We have used four RFLPs and have observed a statistically significant difference only in the allele frequency of the NcoI RFLP. The absence of the varying cutting site (rarer N2 allele) occurs more frequently in the $\mathrm{FH}$ group than in the controls. This suggests that in our London FH sample, a mutation has occurred on an N2 allele and is making a significant contribution to mutations causing FH in this patient group. From this we would predict that a large proportion of the patients possessing a defective LDL receptor gene associated with an N2 allele will have a common mutation, and they may therefore share a common haplotype using the other RFLPs. Further haplotype analysis and receptor binding studies are being carried out to confirm this prediction. It is, however, possible that this observation could have occurred by chance alone and this will need to be confirmed in larger studies. It is possible that the frequency of these four RFLPs is different in populations from different geographical areas. This is the case for polymorphisms of the apo AI/CIII/AIV gene cluster, which show significant differences in allele frequency even within different parts of the UK. ${ }^{36}$ Thus, if the origins of the patient and control groups are not the same, this could lead to the observed differences in frequency. Our patients and controls are all Caucasians from London, but they probably originate from several different European countries.

We have also attempted to use these RFLPs to see if variation in the LDL receptor gene may contribute to the determination of normal serum cholesterol levels in non-FH hyperlipidaemic and normal subjects. For example, a variation in the promoter region of the gene might result in slightly reduced transcription of the gene and thus lower receptor numbers on the cell surface. Alternatively, amino acid changes in the ligand binding region might slightly reduce the affinity for binding LDL, and both of these changes might predispose a subject to develop moderately raised levels of LDL cholesterol. Some family data have been reported ${ }^{37}$ to support the hypothesis that four different 'normal' LDL receptor variants exist, but this has not been confirmed. We have determined the mean cholesterol levels of persons in the normal population with different LDL receptor RFLP genotypes to study the effect of variation at this locus on normal lipid levels. This approach has proved fruitful in the analysis of variation associated with the apo B and apo AI polymorphisms. ${ }^{38-40}$ However, in our control sample there are no statistically significant differences in mean serum cholesterol (table 4), LDL cholesterol, or apo B levels associated with different StuI, PvuII, ApaLI, or NcoI genotypes. Some differences in cholesterol levels associated with the StuI RFLP were noted, and it is possible that these differences would reach statistical significance if repeated in a larger sample. This failure to detect a significant association may be because the RFLPs used are all in the $3^{\prime}$ region of the gene and it is possible that other polymorphisms, particularly those nearer the promoter and ligand binding regions at the $5^{\prime}$ end of the gene, would be more useful. At present we have no evidence that variation at the LDL receptor locus is involved in determining cholesterol levels in the non-FH population.

This work was supported by grants from the British Heart Foundation (RG5), the Family Heart Association, and The Charing Cross Sunley Research Trust. MSJ is supported by a grant from the South African MRC. We would like to thank Dr D W Russell for supplying the LDL receptor probe, Dr Gil Thompson for access to patient samples, and Professor $M$ Marmot, Dr $R$ Houlston, and Dr D Wile for supplying DNA samples. We are also grateful to Miss Naila Loqueman for skilled technical assistance and to Mrs A Wilcox for help in preparing the manuscript.

\footnotetext{
References

1 Harlan WR, Graham JB, Estes EH. Familial hypercholesterolaemia, a genetic and metabolic study. Medicine (Baltimore) 1966;45:77-110.

2 Goldstein JL, Hazzard WR, Schrott HG, Bierman EL, Motulsky AG, Hyperlipidaemia in coronary heart disease. I. Lipid levels in $\mathbf{5 0 0}$ survivors of myocardial infarction. $J$ Clin Invest 1973;52:1533-43.
} 
${ }^{3}$ Frederickson DS, Goldstein JL, Brown MS. The familial hyperlipoproteinaemias. In: Stanbury JB, Wyngaarden JB, Frederickson DS, eds. The metabolic basis of inherited disease. New York: McGraw-Hill, 1978:604-55.

4 Brown MS, Goldstein JL. Expression of the familial hypercholesterolemia gene in heterozygotes-mechanism for a dominant disorder in man. Science 1974;185:61-3.

5 Tolleshaug H, Hobgood KK, Brown MS, Goldstein JL. The LDL receptor locus in familial hypercholesterolaemia. Multiple mutations disrupt transport and processing of a membrane receptor. Cell 1983;32:941-51.

${ }^{6}$ Leonard JV, Whitelaw AGL, Wolff OH, Lloyd JK, Slack J. Diagnosing familial hypercholesterolaemia in children by measuring serum cholesterol. Br Med J 1977;i:1566-8.

${ }^{7}$ Kessling AM, Seed M, Shennen N, Niththyananthan R, Wynn V. Rising cholesterol levels in children at risk of familial hypercholesterolaemia. (Submitted.)

8 Yamamoto T, Davis LG, Brown MS, et al. The human LDL receptor: a cystein-rich protein with multiple Alu sequences in its mRNA. Cell 1984;39:27-38.

9 Lehrman MA, Schneider WJ, Sudhof TC, et al. Mutations in LDL receptor; Alu-Alu recombination deletes exons encoding transmembrane and cytoplasmic domains. Science 1985;227: $140-6$.

10 Lehrman MA, Goldstein JL, Brown MS, Russell DW, Schneider WJ. Internalization-defective LDL receptors produced by genes with nonsense and frameshift mutations that truncate the cytoplasmic domain. Cell 1985;41:735-43.

11 Hobbs HH, Brown MS, Goldstein JL, Russell DW. Deletion of exon encoding cysteine-rich repeat of LDL receptor alters its binding specificity in a subject with familial hypercholesterolaemia. J Biol Chem 1986;261:13114-20.

12 Lehrman MA, Russell DW, Goldstein JL, Brown MS. ExonAlu recombination deletes 5 kilobases from low density lipoprotein receptor gene, producing a null phenotype in familial hypercholesterolaemia. Proc Natl Acad Sci USA 1986;83: 3679-83.

13 Davis CG, Lehrman MA, Russell DW, Anderson RGW, Brown MS, Goldstein JL. The J.D. mutation in familial hypercholesterolaemia: substitution of cysteine for tyrosine in cytoplasmic domain impedes internalization of LDL receptors. Cell 1986;45:15-24.

14 YamamotoT, Bishop RW, Brown MS, Goldstein JL, Russell DW. Deletion in cysteine-rich region of LDL-receptor impedes transport to cell surface in WHHL rabbit. Science 1986;232:1230-7.

15 Lehrman MA, Goldstein JL, Russell DW, Brown MS. Duplication of seven exons in LDL receptor gene caused by Alu-Alu recombination in a subject with familial hypercholesterolaemia. Cell 1987;48:827-35.

${ }^{16}$ Lehrman MA, Schneider WJ, Brown MS, et al. The Lebanese allele at the low density lipoprotein receptor locus. Nonsense mutation produces truncated receptor that is retained in endoplasmic reticulum. J Biol Chem 1987;262:401-10.

17 Horsthemke B, Beisiegel U, Dunning A, Havinga JR, Williamson $R$, Humphries $S$. Unequal crossing-over between two alu-repetitive DNA sequences in the LDL receptor gene: a possible mechanism for the defect in a patient with familial hypercholesterolaemia. Eur J Biochem 1987;164:77-81.

${ }^{18}$ Horsthemke B, Dunning A, Humphries SE. Identification of deletions in the human low density lipoprotein receptor gene. J Med Genet 1987;24:144-7.

19 Hobbs HH, Brown MS, Russell DW, Davignon J, Goldstein JL. Deletion in the gene for the low density lipoprotein receptor in a majority of French Canadians with familial hypercholesterolaemia. N Engl J Med 1987;317:734-7.

20 Leitersdorf E, Hobbs HH. Human LDL receptor gene: two ApaLI RFLPs. Nucleic Acids Res 1987;15:2782.

21 Kotze MJ, Retief AE, Brink PA, Weich HFH. A DNA polymorphism in the human low-density lipoprotein receptor gene. S Afr Med J 1986;70:77-9.
22 Kotze MJ, Langenhoven E, Dietzsch E, Retief AE. A RFLP associated with the low-density lipoprotein receptor gene (LDLR). Nucleic Acids Res 1987;15:376.

${ }^{23}$ Funke H, Klug J, Frossard P, Coleman R, Assmann G. PstI RFLP close to the LDL receptor gene. Nucleic Acids Res 1986;14:7820.

24 Steyn LT, Pretorius A, Brink PA, Bester AJ. RFLP for the human LDL receptor gene (LDLR): BstEII. Nucleic Acids Res 1987;15:4702.

25 Hobbs HH, Esser V, Russell DW. AvalI polymorphism in the human LDL receptor gene. Nucleic Acids Res 1987;15:379.

26 Geisel J, Weisshaar B, Oette K, Mechtel M, Doerfler W. Double MspI RFLP in the human LDL receptor gene. Nucleic Acids Res 1987;15:3943.

${ }^{27}$ Humphries SE, Kessling AM, Horsthemke B, et al. A common DNA polymorphism of the low density lipoprotein (LDL) receptor gene and its use in diagnosis. Lancet 1985; i:1003-5.

${ }^{28}$ Humphries SE, Donald JA, McFadden JJP, et al. The use of polymorphic DNA and protein markers for the third complement component for determining linkage of familial hypercholesterolaemia. Atherosclerosis 1984;52:267-78.

29 Leppert MF, Hasstedt SJ, Holm T, et al. A DNA probe for the LDL receptor gene is tightly linked to hypercholesterolaemia in a pedigree with early coronary heart disease. Am J Hum Genet 1986;39:300-6.

30 Sing CF, Davignon J. Role of apolipoprotein E polymorphism in determining normal plasma lipid and lipoprotein variation. Am J Hum Genet 1985;37:268-85.

31 Utermann G, Kinderman I, Kaffarnick H, Steinmetz A. Apolipoprotein E phenotypes and hyperlipidaemia. Hum Genet 1984;65:232-6.

32 Humphries SE, Donald JA, McFadden JJP, et al. The use of polymorphic DNA and protein markers for the third complement component for determining linkage of familial hypercholesterolaemia. Atherosclerosis 1984;52:267-78.

33 Feinberg AP, Vogelstein B. Addendum. A technique for radiolabelling DNA restriction endonuclease fragments to high specific activity. Anal Biochem 1984;137:266-7.

34 Southern E. Detection of specific sequences among DNA fragments separated by gel electrophoresis. J Mol Biol 1975;98: 503-17.

35 Templeton AR, Sing CF, Kessling A, Humphries SE. A cladistic analysis of phenotypic associations with haplotypes inferred from restriction endonuclease mapping. II. Associations of triglyceride and cholesterol levels with the apolipoprotein AI, CIII, AIV region in a human population. Genetics (in press).

36 Morris SW, Price WH. DNA sequence polymorphisms in the apolipoprotein AI/CIII gene cluster. Lancet 1985;ii:1127-8.

37 Maartmann-Moe K, Maginus P, Golden W, Berg K. Genetics of the low density lipoprotein receptor. III. Evidence for multiple normal alleles at the low density lipoprotein receptor locus. Clin Genet 1981;20:113-29.

38 Law A, Powell LM, Brunt H, et al. Common DNA polymorphism within coding sequence of apolipoprotein $B$ gene associated with altered lipid levels. Lancet 1986;i:1301-3.

39 Talmud PJ, Barni N, Kessling AM, et al. Apolipoprotein B gene variants are involved in the determination of serum cholesterol levels: a study in normal and hyperlipidaemic individuals. Atherosclerosis 1987;67:81-9.

40 Kessling AM, Rajput-Williams J, Bainton D, et al. DNA polymorphisms of the apolipoprotein AII and AI-CIII-AIV genes: a study in men selected differences in high density lipoprotein cholesterol concentration. Am J Hum Genet $1988 ; 42: 458-67$.

Correspondence and requests for reprints to Miss R Taylor, The Charing Cross Sunley Research Centre, Lurgan Avenue, London W6 8LW. 